\title{
Epidemiologic evaluation of patients with major burns and recommendations for burn prevention
}

\author{
Majör yanıklı hastaların epidemiyolojik açıdan incelenmesi ve \\ yanıktan korunma yolları
}

İlhan ÇífTÇI, ${ }^{1}$ Kemal ARSLAN, ${ }^{2}$ Zeynep ALTUNBAŞ, ${ }^{3}$ Fatih KARA,,${ }^{4}$ Hüseyin YILMAZ ${ }^{5}$

\section{BACKGROUND}

Burns are an important health problem in our country and in the world. In our study, we aimed to epidemiologically analyze the patients who were hospitalized in a burn unit that serves 3 million individuals in Central Anatolia.

\section{METHODS}

Records of 457 patients who had been hospitalized in the burn unit during the period 2008-2010 were analyzed retrospectively. Patients were assessed in terms of gender, age, burn area, burn depth, admission time to the health center, burn region, and factors causing burns.

\section{RESULTS}

Most (44.6\%) of the patients were in the $0-5$ age group. Burn surface area was detected as $11.6 \pm 8.5 \%$. Patients had reached the health center in $252.8 \pm 892.5$ minutes. While $82.7 \%$ of the patients had second degree burns, $17.3 \%$ had third degree burns. Most burns were on the extremities $(39.6 \%)$. The most common burn agent was scalds with hot liquids (54.1\%).

\section{CONCLUSION}

In our study, children in the 0-5 age group were found to be the most commonly affected group with respect to indoor burns. The basic contributing factor is that children spend more time in the house and are more active. Scalding burns may be prevented when greater care is taken when using hot liquids that may lead to indoor burns. Informing parents on this issue is of first priority.

Key Words: Burn prevention; burns; epidemiology; hospitalized patients.

\section{AMAÇ}

Yanıklar ülkemizde ve dünyada önemli bir sağlık sorunudur. Bu çalışmamızda amacımız, Orta Anadolu'da yaklaşık 3 milyon nüfusa hitap eden yanık ünitesindeki hastala$\mathrm{r} 1$ incelemektir.

\section{GEREÇ VE YÖNTEM}

2008 ile 2010 yılları arasında yatarak tedavi gören $457 \mathrm{ka}-$ yıtlı hasta geriye dönük olarak incelendi. Olgular cinsiyet, yaş, yanık alanı, yanık derinliği, sağlık kuruluşuna başvuru süresi, yanık bölgesi ve yanık nedenleri açısından karş1laştırıldı.

\section{BULGULAR}

Olguların çoğunluğunu $(\% 44,6) \quad 0-5$ yaş grubu çocuk-

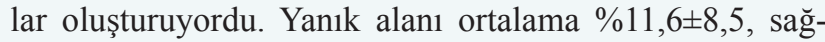
lik merkezine başvuru süresi ortalama $252,8 \pm 892,5$ dakika olarak bulundu. Olguların \%82,7'si 2. derece, \%17,3'ü 3. derece yanık derinliğine sahipti. Yanık bölgesi ekstremitede en fazla idi $(\% 39,6)$. Yanık nedeni olarak sıcak sıvı haşlanma yanıkları fazla idi $(\% 54,1)$.

\section{SONUÇ}

Çalışmamızda 0-5 yaş grubu olgular en fazla etkilenen gruptu ve genellikle yanıklar ev içinde oluşmaktaydı. Bu konuda çocukların ev içinde geçirdikleri sürenin fazla olması ve çocukların bu dönemde çok hareketli olması temel faktörlerdir. Yanıkla mücadelede, haşlanma yanıklarının önlenmesi ve ebeveyn bilgilendirmesinin sağlanması en önemli aşama olmalıdır.

Anahtar Sözcükler: Yanık önlenmesi, yanıklar, epidemiyoloji; hastanede yatan hastalar.

\footnotetext{
Departments of ${ }^{1}$ Pediatric Surgery, ${ }^{4}$ Public Health, ${ }^{5}$ General Surgery, Selcuk University, Selcuklu Faculty of Medicine, Konya; Departments of ${ }^{2}$ General Surgery, ${ }^{3}$ Plastic and Reconstructive Surgery, Konya Training and Research Hospital, Konya, Turkey.
}

Selçuk Üniversitesi Selçuklu Tıp Fakültesi, Çocuk Cerrahisi Anabilim Dalı, Halk Sağlığı Anabilim Dalı, Genel Cerrahi Anabilim Dalı, Konya; Konya Eğitim ve Arastırma Hastanesi, ${ }^{2}$ Genel Cerrahi Kliniği, ${ }^{3}$ Plastik ve Rekonstrüktif Cerrahi Kliniği, Konya. 
Burns represent an important health problem, as they lead to significantly high rates of mortality and morbidity worldwide. In addition, burns are associated with multiple problems in the community. The most effective way to overcome this problem is to prevent burns and treat existing burns quickly and effectively. ${ }^{[1-3]}$ Patients with burns are affected physically and psychologically in the long term. ${ }^{[4-6]}$ Therefore, preventing burns is crucial for both human health and the country's economy, given that burn treatment is enduring and expensive. ${ }^{[7,8]}$ Despite the presence of studies about minor and moderate burns in the literature, there is limited data about our country. ${ }^{[9]}$ Those types of burns are treated in outpatient clinics in many institutions. Some patients with minor and moderate burns do not even visit a health center. Treatment and follow-up of patients with major burns are done carefully in newly established burn units. ${ }^{[10,11]}$

The Burn Unit of the Konya Research and Training Hospital was established in 2008 in central Anatolia. With 13 beds, it serves approximately 3 million individuals. One pediatric surgeon, one general surgeon, and one plastic surgeon work in this unit. It is also supported by other specialists in the hospital when needed.

The aim of this study was to investigate the epidemiological characteristics of 457 major burn patients admitted to the Burn Unit of the Konya Research and Training Hospital between 2008 and 2010, according to the American Burn Association (ABA) criteria. ${ }^{[12]}$ In order to design and implement an effective prevention effort, it is essential to define the epidemiology and causes that should be addressed to achieve the maximum benefit.

\section{MATERIALS AND METHODS}

A total of 457 patients who were admitted to the Burn Unit of the Konya Research and Training Hospital between 2008 and 2010, who were hospitalized and treated according to ABA criteria, were included in the study. Patient files were analyzed retrospectively in terms of age; cause of burn; admission time; burn injury site, area, depth, and location; season; and gender.

Patients were divided into five groups as follows: $\leq 5$ years, 6-12 years, 13-18 years, 19-65 years, and $\geq 65$ years. Patients were divided into groups according to burn agent, such as scalding, flame, contact, chemical, and electrical burn. Admission time was recorded as the duration from burn development to reaching a health institution according to the reports of the patient or relatives. Burn areas were categorized as face/neck, trunk, perineum, extremity, and whole body. Burn area was estimated as the ratio of the burn area to the total body surface (\%). Burns characterized with bulla formation affecting the epidermis and some part of the dermis were classified as second degree, whereas burns characterized with color change in which the dermis was affected were classified as third degree. The location in which the burn developed was divided into two groups as indoor or outdoor.

\section{Statistical Analysis}

Data were transferred to computer, and faults were controlled. Data were summarized as mean \pm standard deviation and percentages. Comparisons between two groups were performed using the Mann-Whitney $\mathrm{U}$ test. Comparisons between more than two groups were conducted using Kruskal-Wallis variance analysis. Significant parameters were compared using the Bonferroni correction in the Mann-Whitney U test. Comparisons of categorical data were done using chisquare tests. The level of significance was set at 0.05 .

\section{RESULTS}

A total of 457 patients with major burns according to ABA grading who had been hospitalized and treated in the Burn Unit of the Konya Research and Training Hospital were examined. The mean age was $16.9 \pm 19.3$ years $(17.7 \pm 20.6$ for females, $16.4 \pm 18.5$ for males; $p>0.05$ ). Of the patients, $36.8 \%$ were females and $63.2 \%$ were males. The majority of patients were in the $0-5$ age group $(44.6 \%, n=204)$. As shown in Table 1, no difference was detected across age groups according to gender $(\mathrm{p}>0.05)$.

The mean burn area was $11.6 \pm 8.5 \%$. While the mean burn surface area did not differ according to gender, place of burn, season, or age group ( $p>0.05)$, as shown in Table 2, a significant difference was detected according to burn degree, burn cause and burn site $(\mathrm{p}<0.05)$. Although the mean burn area was higher in second degree burns compared to scalding burns, it was lower in extremity burns.

Patients reached a health center within $252.8 \pm 892.5$ minutes before their treatment began. While there was no difference in terms of admission time according to gender, burn place, burn degree, burn cause, burn site, and burn season, a significant difference was detected in admission times according to age. As shown in Table 3, individuals in the 0-5 and 19-65 age groups

Table 1. Distribution of patients according to age groups and gender

\begin{tabular}{lccc}
\hline & \multicolumn{2}{c}{ Gender } & \\
\cline { 2 - 3 } Age groups & Female n (\%) & Male n (\%) & Total (n) \\
\hline 0-5 years & $77(37.7)$ & $127(62.3)$ & 204 \\
6-12 years & $22(36.7)$ & $38(63.3)$ & 60 \\
13-18 years & $10(30.3)$ & $23(69.7)$ & 33 \\
19-65 years & $54(37.0)$ & $92(63.0)$ & 146 \\
$\geq 65$ years & $5(35.7)$ & $9(64.3)$ & 14 \\
\hline
\end{tabular}

$\chi^{2}=0.69, \mathrm{p}=0.95, \mathrm{SD}=4$. 
Table 2. Comparison of burn area according to some variables

\begin{tabular}{|c|c|c|}
\hline & Burn area $(\%)$ & $\mathrm{p}$ \\
\hline \multicolumn{3}{|l|}{ Gender } \\
\hline Female & $11.1 \pm 7.9$ & 0.431 \\
\hline Male & $12.0 \pm 8.8$ & \\
\hline \multicolumn{3}{|l|}{ Degree } \\
\hline 2nd degree & $12.4 \pm 8.6$ & 0.000 \\
\hline 3rd degree & $7.9 \pm 6.8$ & \\
\hline \multicolumn{3}{|l|}{ Place } \\
\hline Indoor & $11.3 \pm 8.0$ & 0.375 \\
\hline Outdoor & $12.5 \pm 9.6$ & \\
\hline \multicolumn{3}{|l|}{ Age group } \\
\hline $0-5$ years & $10.8 \pm 7.5$ & 0.057 \\
\hline $6-12$ years & $10.2 \pm 7.5$ & \\
\hline $13-18$ years & $12.9 \pm 8.3$ & \\
\hline $19-65$ years & $12.9 \pm 9.9$ & \\
\hline$\geq 65$ years & $14.0 \pm 7.8$ & \\
\hline \multicolumn{3}{|l|}{ Cause } \\
\hline Liquid-vapor & $11.6 \pm 7.5$ & 0.000 \\
\hline Chemical & $12.2 \pm 10.4$ & \\
\hline Contact & $5.3 \pm 4.1^{*}$ & \\
\hline Flame & $12.4 \pm 7.0$ & \\
\hline Electric & $12.2 \pm 10.1$ & \\
\hline \multicolumn{3}{|l|}{ Region } \\
\hline Face-neck & $10.1 \pm 5.9$ & 0.000 \\
\hline Trunk & $17.0 \pm 10.6^{\S}$ & \\
\hline Perineum & $11.0 \pm 6.5$ & \\
\hline Extremity & $8.5 \pm 5.5$ & \\
\hline Whole body & $24.5 \pm 11.5^{\S}$ & \\
\hline \multicolumn{3}{|l|}{ Season } \\
\hline Winter & $10.9 \pm 6.1$ & 0.686 \\
\hline Spring & $12.5 \pm 8.9$ & \\
\hline Summer & $11.0 \pm 8.3$ & \\
\hline Autumn & $12.0 \pm 9.2$ & \\
\hline
\end{tabular}

* Different from other causes; $§ 2-5$ have similar burn percentage but different from other burn regions.

reached a health center earlier than those in the other age groups $(p<0.05)$. Although no difference was detected in mean age according to gender and season, a difference was found in mean age according to burn place, burn site, and burn cause $(\mathrm{p}<0.05)$. While scalding burns were seen in younger individuals, flame burns were seen in older individuals (Table 4). No difference was found in burn causes, burn site, age group, and burn degree according to gender $(\mathrm{p}>0.05)$. However, outdoor burns were found significantly less often in females $(6.5 \%)$ compared to males $(39.1 \%)$ $\left(\mathrm{p}=0.000, \chi^{2}=56.9\right)$.

Of the patients, $82.7 \%$ had second degree burns and $17.3 \%$ had third degree burns. No difference was detected in burn degree in terms of burn place $(\mathrm{p}>0.05)$. Nevertheless, as shown in Table 5, third degree burns were found more frequently in individuals $\geq 65$ years,
Table 3. Comparison of admission times according to some variables

\begin{tabular}{|c|c|c|}
\hline & Admission time (min) & $\mathrm{p}$ \\
\hline \multicolumn{3}{|l|}{ Gender } \\
\hline Female & $276.3 \pm 1088.8$ & 0.919 \\
\hline Male & $239.2 \pm 757.1$ & \\
\hline \multicolumn{3}{|l|}{ Degree } \\
\hline 2nd degree & $210.5 \pm 829.1$ & 0.456 \\
\hline 3rd degree & $455.3 \pm 1132.9$ & \\
\hline \multicolumn{3}{|l|}{ Place } \\
\hline Indoor & $298.9 \pm 997.6$ & 0.104 \\
\hline Outdoor & $129.1 \pm 495.5$ & \\
\hline \multicolumn{3}{|l|}{ Age group } \\
\hline $0-5$ years & $175.2 \pm 814.5^{*}$ & 0.004 \\
\hline $6-12$ years & $539.0 \pm 1216.5$ & \\
\hline $13-18$ years & $363.8 \pm 1179.9$ & \\
\hline $19-65$ years & $195.0 \pm 708.5^{*}$ & \\
\hline$\geq 65$ years & $499.6 \pm 1109.0$ & \\
\hline \multicolumn{3}{|l|}{ Cause } \\
\hline Liquid-vapor & $286.9 \pm 1025.4$ & 0.130 \\
\hline Chemical & $236.3 \pm 768.1$ & \\
\hline Contact & $508.8 \pm 1193.1$ & \\
\hline Flame & $104.6 \pm 279.5$ & \\
\hline Electric & $38.5 \pm 41.9$ & \\
\hline \multicolumn{3}{|l|}{ Region } \\
\hline Face-neck & $191.4 \pm 653.5$ & 0.151 \\
\hline Trunk & $224.8 \pm 755.6$ & \\
\hline Perineum & $350.2 \pm 935.0$ & \\
\hline Extremity & $307.5 \pm 1102.9$ & \\
\hline Whole body & $23.2 \pm 16.6$ & \\
\hline \multicolumn{3}{|l|}{ Season } \\
\hline Winter & $128.5 \pm 501.8$ & 0.291 \\
\hline Spring & $244.3 \pm 797.0$ & \\
\hline Summer & $288.1 \pm 917.3$ & \\
\hline Autumn & $275.6 \pm 1035.1$ & \\
\hline
\end{tabular}

* Significantly lower compared to $\geq 65$ years.

as well as in those with contact burns, burns in the spring season, and burns of the extremities $(p<0.05)$.

Among the hospitalized patients, burns were seen most frequently on the extremities $(39.6 \%)$, followed by the trunk $(26.0 \%)$, face and neck $(25.2 \%)$, perineum $(6.8 \%)$, and whole body (2.4\%). Burns were most commonly caused by scalding $(54.1 \%)$, followed by flames $(20.7 \%)$, chemicals $(13.8 \%)$, objects $(6.4 \%)$, and electricity $(5.1 \%)$.

When the place of burn injury was analyzed according to age, it was found that they occurred indoors in $84.3 \%$ of the $\leq 5$ age group, $78.3 \%$ of the $6-12$ age group, $57.6 \%$ of the $13-18$ age group, $56.8 \%$ of the $19-65$ age group, and $85.7 \%$ of the $\geq 65$ age group. Outdoor burns were observed most frequently in the 19-65 age group $\left(\mathrm{p}=0.000, \chi^{2}=38.4, \mathrm{SD}=4\right)$ followed by $13-18$ age group $\left(\mathrm{p}=0.004, \chi^{2}=13.3, \mathrm{SD}=3\right)($ Fig. 1$)$. 
Table 4. Comparison of mean ages according to some variables

\begin{tabular}{lcc}
\hline & Age & $\mathrm{p}$ \\
\hline Gender & & \\
Female & $17.7 \pm 20.5$ & 0.828 \\
Male & $16.4 \pm 18.5$ & \\
Degree & & \\
$\quad$ 2nd degree & $15.2 \pm 17.9$ & 0.001 \\
3rd degree & $24.8 \pm 23.5$ & \\
Place & & \\
Indoor & $15.2 \pm 19.9$ & 0.000 \\
Outdoor & $21.3 \pm 16.9$ & \\
Cause & & \\
Liquid-vapor & $11.0 \pm 16.2$ & 0.000 \\
Chemical & $14.8 \pm 19.5$ & \\
Contact & $17.1 \pm 17.5$ & \\
Flame & $30.6 \pm 20.6^{*}$ & \\
Electric & $28.1 \pm 12.8^{*}$ & \\
Region & & \\
Face-neck & $21.7 \pm 19.5$ & 0.000 \\
Trunk & $14.5 \pm 17.6^{\S}$ & \\
Perineum & $18.3 \pm 16.6$ & \\
Extremity & $15.1 \pm 20.4 \S$ & \\
Whole body & $16.1 \pm 17.2$ & \\
Season & $14.5 \pm 19.9$ & \\
Winter & $16.7 \pm 18.9$ & \\
Spring & $16.6 \pm 19.8$ & \\
Summer & Autumn & \\
\hline
\end{tabular}

*Mean age was similar in flame and electric burns; however, greater than other burn causes; $\S$ Mean age for 2 nd and 4 th regions was similar but lower than for other burn regions.

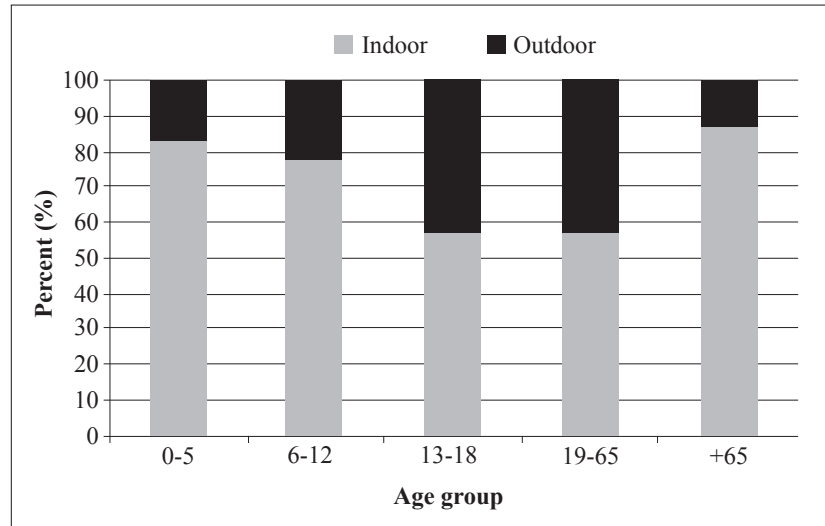

Fig. 1. Distribution of burn accidents according to age and place.

\section{DISCUSSION}

Burn injury is a significant public health concern. Severe burns can be lethal. In addition, survivors often suffer from disfiguring and disabling scar, psychological trauma, and loss of productive years. Many epidemiologic studies about burns are available in Turkey, ${ }^{[2,10,11,13]}$ with the primary aim of developing a burn profile and promoting prevention.
Table 5. Comparison of burn degree according to some variables

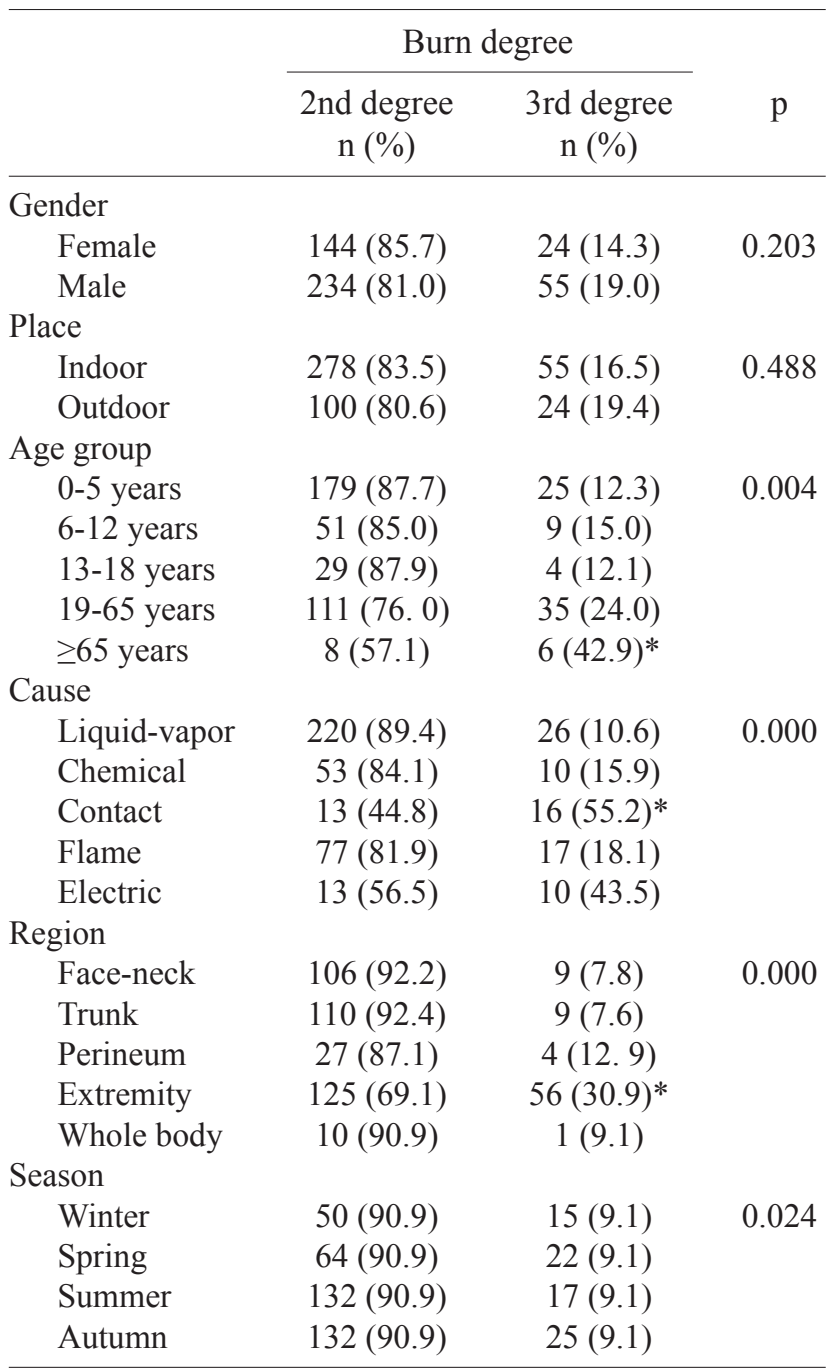

Burns may lead to fear and psychological damage in patients and their loved ones. In addition, health care professionals have trouble approaching these patients. We analyzed outcomes over approximately two years in a clinic that was established to fight burns and intervene with burn patients. In this study, we assessed prevention and started treatment earlier rather than later. The majority of the study population in our investigation was male, a finding that corresponded with information in other reports. ${ }^{[9,10]}$

Consistent with the literature, a vast majority of the patients included children under 18 years of age $(65.0 \%)$, with many being $\leq 5$ years $(44.6 \%) .{ }^{[9-11,13-}$ ${ }^{15]}$ This result indicates that burn prevention efforts should be emphasized among this age group. Reaching this age group may only be possible by reaching parents. Focusing parents' attention on burn injury and protection from burns is crucial. Thus, informing and educating them should be in the foreground in the fight against burns. Schools, parents and administrators 
should collaborate to offer this education. ${ }^{[16]}$ Several researchers have found success by working in this manner ${ }^{[17]}$ The difference between burn agents is also present in the treatment of children. For this reason, the approach to children's treatment is different than that of adults. ${ }^{[18]}$

In this study, scalding was the leading cause of burns, followed by fire. This finding is consistent with those of other studies ${ }^{[1,14-16]}$ and inconsistent with another ${ }^{[19]}$ The main contributor to scalding injuries is the habit of drinking tea in the Turkish population and traditional tea-making tools that can lead to severe accidents. ${ }^{[11,20]}$ The traditional tea habit should be questioned. In addition, safer methods should be developed for protection. Given that the kitchen or cooking area and open fires are dangerous, certain steps could and should be taken to intervene in these specific areas, preventing the possibility of burn injuries in Turkey.

Contact burns were found to be significantly more common in the spring and among individuals $\geq 65$ years. The reason for this is the relative reduction of other burns. Contact burns related to contact with hot ovens are significantly more common in this age group due to carelessness as a result of advancing age. There were higher rates of contact burns among individuals aged 19-65 years; however, this difference was not statistically significant. This age group includes actively working individuals. These types of burns are seen frequently due to occupational accidents. ${ }^{[21]}$ Occupational safety and worker protection should be obtained for prevention. Preventive measures by employers may not be enough; worker education should also be provided.

The mean admission time was 253 minutes. We could not make comparisons due to the small number of studies on this topic; however, we considered the admission time to be long. Future studies should be performed to examine these patterns. Early treatment is important, especially when dealing with burns involving wide surfaces. Getting the patient to a health center and a burn unit quickly and safely is crucial in terms of relieving pain and preventing foreign body contact and infection. The first intervention should be effective in burns. Minor burns can be treated with first intervention and wound care. ${ }^{[19]}$ Directing and transporting patients to the appropriate unit is crucial for burn injuries as well as early treatment. Treatment of patients with minor or moderate burns differs from treatment of those with major burns. ${ }^{[22]}$ Patients' suffering due to pain and prevention of incorrect treatments may be hindered as admission time decreases.

The burn surface area is wider in second degree burns compared to third degree burns. Second degree burns usually develop as a result of scalding, whereas third degree burns usually develop as a result of contact burns. This result should be viewed as normal, as the area of a contact burn is smaller. Second degree burns were more common compared to third degree burns in all groups in this study. This finding is consistent with the literature. ${ }^{[23]}$

Also consistent with the literature, there was no significant difference according to gender. ${ }^{[9,16,23]}$ Outdoor burn injuries were less common among females. Traditionally, adult women do all of the cooking for the family in Turkey; therefore, they are at greater risk for domestic burns. Preschool boys spend most of their time at home, whereas they are outside the home the majority of the time when they are older. Specifically, they are either in school or outside playing. This gender-related pattern in Turkey continues into adulthood. Most adult women work at home, spending more time inside their houses, especially during cold seasons, while most men spend their time outside and are less susceptible to burns in home settings.

With regard to outdoor burns, we found that some of the most important factors were downed power lines (especially in rural areas), children playing with fire or fireworks, unlawful entry into transformer stations, road accidents, and lightning strikes. These types of injuries cause more severe burns, which is why third degree injuries were more frequent in the burns that took place outdoors.

The rate of indoor burn injuries was relatively high (72.9\%). This finding is consistent with those of other studies. ${ }^{[14,16]}$ The main factor contributing to the high ratio of indoor burns was accidents involving children. Children in the 0-5 age group were found to be most affected by indoor burns. We found that the most frequent medically attended injuries were among children who were already walking and up to 16 months of age, which we characterized as "beginning to walk and becoming inquisitive". Rates of accidental burns were high among children, as they spend much of their time at home and are active. Thus, reducing indoor burn exposure should be in the foreground among burn protection activities. In particular, scalding burns should be prevented.

Parent education is important. The house should be arranged in consideration of the children. In addition, children should avoid materials that could cause burns. Further, they should not be left unattended. Females are viewed as being more affected by indoor accidents, as they stay home longer than males. This study focuses our attention on a specific group that is at risk for burn injury in a well-defined community. Some of the risk factors, such as cooking and heating techniques, appliances, and behavior trends, should be changed. 
In conclusion, burn injury has become a significant public health problem in Turkey and the world. To reduce the burden of burn injury, it is necessary to increase current efforts in community education. The family, schools, manufacturers, and government should all be involved. The most important step in fighting burns is protecting children and preventing burns in this age group. Indoor accidents are important for burn injuries. Children are most affected by these accidents. In addition, children should avoid factors that may lead to burns.

Information and education for parents are essential components of burn prevention among children. Parents should be educated about the severity of burn injuries and the difficulty of treatment. The causes of scalding burns should be clarified, and measures should be taken.

Individuals with burn injuries should be transported to a health center quickly and safely. Moreover, patients with major burns should be transported to a special burn unit. Contact burns cause small, but deep burns. Therefore, treatment should take seasonal differences into consideration. The role of indoor accidents is great in burn injuries. Communication tools, such as radio and television, can be useful because they reach large populations.

\section{REFERENCES}

1. Gueugniaud PY. Management of severe burns during the $1 \mathrm{st}$ 72 hours. Ann Fr Anesth Reanim 1997;16:354-69. CrossRef

2. Coste J, Wasserman D, Venot A. Predicting mortality in adult burned patients: methodological aspects of the construction and validation of a composite ratio scale. J Clin Epidemiol 1996;49:1125-31. CrossRef

3. den Hertog PC, Blankendaal FA, ten Hag SM. Burn injuries in The Netherlands. Accid Anal Prev 2000;32:355-64. CrossRef

4. Shelby J, Sullivan J, Groussman M, Gray R, Saffle J. Severe burn injury: effects on psychologic and immunologic function in noninjured close relatives. J Burn Care Rehabil 1992;13:58-63. CrossRef

5. Davydow DS, Katon WJ, Zatzick DF. Psychiatric morbidity and functional impairments in survivors of burns, traumatic injuries, and ICU stays for other critical illnesses: a review of the literature. Int Rev Psychiatry 2009;21:531-8. CrossRef

6. Bosquet Enlow M, Kassam-Adams N, Saxe G. The Child Stress Disorders Checklist-Short Form: a four-item scale of traumatic stress symptoms in children. Gen Hosp Psychiatry 2010;32:321-7. CrossRef
7. Hemington-Gorse SJ, Potokar TS, Drew PJ, Dickson WA. Burn care costing: the Welsh experience. Burns 2009;35:37882. CrossRef

8. Taghizadeh R, Gilbert PM. Comparison of commonly used mesher types in burns surgery revisited. Burns 2008;34:10910. CrossRef

9. Sadeghi-Bazargani H, Mohammadi R, Svanstrom L, Ekman $\mathrm{R}$, Arshi S, Hekmat S, et al. Epidemiology of minor and moderate burns in rural Ardabil, Iran. Burns 2010;36:933-7. CrossRef

10. Anlatici R, Ozerdem OR, Dalay C, Kesiktaş E, Acartürk S, Seydaoğlu G. A retrospective analysis of 1083 Turkish patients with serious burns. Burns 2002;28:231-7. CrossRef

11. Sakallioğlu AE, Başaran O, Tarim A, Türk E, Kut A, Haberal M. Burns in Turkish children and adolescents: nine years of experience. Burns 2007;33:46-51. CrossRef

12. [No authors listed] Hospital and prehospital resources for optimal care of patients with burn injury: guidelines for development and operation of burn centers. American Burn Association. J Burn Care Rehabil 1990;11:98-104.

13. Haberal M, Uçar N, Bilgin N. Epidemiological survey of burns treated in Ankara, Turkey and desirable burn-prevention strategies. Burns 1995;21:601-6. CrossRef

14. Chien WC, Pai L, Lin CC, Chen HC. Epidemiology of hospitalized burns patients in Taiwan. Burns 2003;29:582-8. CrossRef

15. den Hertog PC, Blankendaal FA, ten Hag SM. Burn injuries in The Netherlands. Accid Anal Prev 2000;32:355-64. CrossRef

16. Kai-Yang L, Zhao-Fan X, Luo-Man Z, Yi-Tao J, Tao T, Wei $\mathrm{W}$, et al. Epidemiology of pediatric burns requiring hospitalization in China: a literature review of retrospective studies. Pediatrics 2008;122:132-42. CrossRef

17. Xin W, Yin Z, Qin Z, Jian L, Tanuseputro P, Gomez M, et al. Characteristics of 1494 pediatric burn patients in Shanghai. Burns 2006;32:613-8. CrossRef

18. Herndon DN, Rutan RL, Rutan TC. Management of the pediatric patient with burns. J Burn Care Rehabil 1993;14:38. CrossRef

19. Avşaroğullari L, Sözüer E, Ikizceli I, Kekeç Z, Yürümez Y, Ozkan S. Adult burn injuries in an Emergency Department in Central Anatolia, Turkey: a 5-year analysis. Burns 2003;29:571-7. CrossRef

20. Reis E, Yasti AC, Kerimoğlu RS, Dolapçi M, Doğanay M, Kama NA. The effects of habitual negligence among families with respect to pediatric burns. Ulus Travma Acil Cerrahi Derg 2009; 15:607-10.

21. Celikoz B, Achauer BM, VanderKam VM. Hot-press hand burn treatment. J Burn Care Rehabil 1998;19:128-30. CrossRef

22. Türegün M, Sengezer M, Selmanpakoglu N, Celiköz B, Nişanci M. The last 10 years in a burn centre in Ankara, Turkey: an analysis of 5264 cases. Burns 1997;23:584-90. CrossRef

23. Frans FA, Keli SO, Maduro AE. The epidemiology of burns in a medical center in the Caribbean. Burns 2008;34:11428. CrossRef 